\title{
CAEP 2016 Academic Symposium on Education Scholarship: Training our Future Clinician Educators in Emergency Medicine
}

Robert A. Woods, MD, MMEd*; Jennifer D. Artz, PhD ${ }^{\ddagger}$; Benoit Carrière, MD, MHPE ${ }^{\S}$; Simon Field, MD, MEd"; James Huffman, MD**; Sandy L. Dong, MD, MSc ${ }^{\dagger+}$; Farhan Bhanji, MD, MSc(HPE) ${ }^{\ddagger \neq}$; Stella Yiu, $\mathrm{MD}^{\S \S}$; Sheila Smith, $\mathrm{MD}^{\dagger}$; Rose Mengual, MD***; Chris Hicks, MD, MEd ${ }^{\text {Tाँ; }}$, Jason Frank, MD, MA(Ed) ${ }^{\S \S}$

\section{ABSTRACT}

Objective: To develop consensus recommendations for training future clinician educators (CEs) in emergency medicine (EM).

Methods: A panel of EM education leaders was assembled from across Canada and met regularly by teleconference over the course of 1 year. Recommendations for CE training were drafted based on the panel's experience, a literature review, and a survey of current and past EM education leaders in Canada. Feedback was sought from attendees at the Canadian Association of Emergency Physicians (CAEP) annual academic symposium. Recommendations were distributed to the society's Academic Section for further feedback and updated by a consensus of the expert panel.

Results: Recommendations were categorized for one of three audiences: 1) Future CEs; 2) Academic departments and divisions (AD\&D) that support training to fulfill their education leadership goals; and 3) The CAEP Academic Section. Advanced medical education training is recommended for any emergency physician or resident who pursues an education leadership role. Individuals should seek out mentorship in making decisions about career opportunities and training options. AD\&D should regularly perform a needs assessment of their future CE needs and identify and encourage potential individuals who fulfill education leadership roles. AD\&D should develop training opportunities at their institution, provide support to complete this training, and advocate for the recognition of education scholarship in their institutional promotions process. The CAEP Academic Section should support mentorship of future CEs on a national scale.

Conclusion: These recommendations serve as a framework for training and supporting the next generation of Canadian EM medical educators.

\section{RÉSUMÉ}

Objectif: Le projet visait à élaborer des recommandations consensuelles sur la formation des futurs médecins enseignants (ME) en médecine d'urgence (MU).

Méthode: Un groupe de meneurs en enseignement de la MU provenant de toutes les régions du Canada a été formé et s'est réuni régulièrement par téléconférence sur une période d'un an. Les recommandations concernant la formation des ME reposaient sur l'expérience du groupe, un examen de la documentation scientifique et une enquête menée parmi les meneurs présents et passés en matière d'enseignement de la MU, au Canada. Les participants au Symposium sur les affaires universitaires de l'Association canadienne des médecins d'urgence (ACMU), qui se tient chaque année, ont eu l'occasion de donner de la rétroaction. Les recommandations ont aussi été transmises à la section des affaires universitaires de I'Association pour rétroaction, puis celles-ci ont été mises à jour par voie de consensus, par un groupe d'experts.

Résultats: Les recommandations ont été divisées en catégories selon l'un des trois groupes suivants : 1) les futurs ME; 2) les départements et divisions universitaires (DDU) qui soutiennent la formation afin de poursuivre leurs buts de chefs de file en enseignement; 3) la section des affaires universitaires de I'ACMU. Une formation spécialisée en enseignement de la médecine est recommandée pour tout médecin d'urgence ou tout résident désireux de jouer un rôle de meneur en enseignement. Les personnes intéressées devraient s'adresser à des mentors pour les éclairer dans leurs prises de décision concernant les perspectives de carrière et les possibilités de formation. Quant aux DDU, ils devraient procéder régulièrement à une évaluation de leurs besoins en futurs $M E$, et repérer des personnes susceptibles de faire de bons ME et les encourager à jouer pleinement leur rôle de meneur en enseignement. De plus,

From the *Department of Emergency Medicine and tDepartment of Academic Family Medicine, University of Saskatchewan, Saskatoon, SK; ‡Canadian Association of Emergency Physicians, Ottawa, ON; §Department of Pediatrics, Université de Montréal, Montreal, QC; ๆDepartment of Emergency Medicine, Dalhousie University, Halifax, NS; **Department of Emergency Medicine, University of Calgary, Calgary, AB; $\uparrow+D e p a r t m e n t$

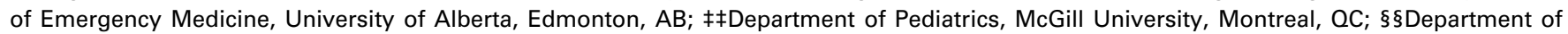
Emergency Medicine, University of Ottawa, Ottawa, ON; I†ाDivision of Emergency Medicine, Department of Medicine, University of Toronto, Toronto, ON; and the ***Discipline of Emergency Medicine, Memorial University, St. John's, NL.

Correspondence to: Robert A. Woods, Room 2689, Royal University Hospital, Saskatoon, SK S7N0W8; Email: rob.woods@usask.ca 
les DDU devraient offrir des possibilités de formation dans leur établissement, fournir du soutien pour compléter la formation et promouvoir la reconnaissance des travaux scientifiques en enseignement dans le processus de promotion de leur établissement. Enfin, la section des affaires universitaires de I'ACMU devrait soutenir le mentorat des futurs ME, à l'échelle nationale.
Conclusions: Ces recommandations servent de cadre pour la formation de la future génération de médecins enseignants en MU au Canada, et pour le soutien à lui accorder.

Keywords: clinician educator, emergency medicine, faculty development, training, medical education, Masters in medical education

\section{INTRODUCTION}

Emergency medicine (EM) education in Canada is changing and evolving rapidly. Simulation, ${ }^{1}$ point-ofcare ultrasound, ${ }^{2}$ Free Open Access Medical (FOAM) Education, ${ }^{3}$ competency-based medical education, ${ }^{4}$ and drive to produce sound education scholarship ${ }^{5}$ exemplify a paradigm shift in both the content and delivery of medical education. As the complexity of medical training increases, emergency physicians (EPs) who take on education leadership roles require expertise in curriculum development, instructional methods, assessment, faculty development, scholarship, and more. Accordingly, the manner in which education leaders are identified, trained, and supported needs to be clearly defined.

The clinician educator (CE) is defined as a clinician who is active in a health professional practice and applies theory to education practice, engages in education scholarship, and serves as a consultant to other professionals on education issues. ${ }^{6}$ EPs in education leadership roles might not fulfill all aspects of this definition, due in part to a lack of formal training for CEs (in contrast to well-defined training pipelines for clinician scientists). In 2013, the Canadian Association of Emergency Physicians (CAEP) Academic Symposium made recommendations for defining education scholarship ${ }^{7}$ and developing and supporting scholars, ${ }^{8}$ along with a "how to" guide for education scholarship. ${ }^{9}$ The goal of the 2016 consensus process is to help EM residents and early career EPs with an interest in education understand the options for training and support requisite for developing expertise in education.

\section{Formation of an expert panel}

An expert panel of Canadian EM education leaders was assembled with attention to the following factors: geographic representation, language, scope of practice, training route, previous and present education leadership roles, and advanced training in medical education. The final panel composition included 11 EPs representing 9 Canadian medical schools from both French and English speaking schools. The panel included EPs with certification from the College of Family Physicians of Canada through the Special Competence in Emergency Medicine (CCFP$\mathrm{EM}$ ), training through the Royal College of Physicians and Surgeons of Canada (FRCPC), and training in pediatric EM through the Royal College (FRCPC-PEM). The panel represented a variety of education leadership positions and a mix of advanced training in medical education. The panel met monthly over the course of a year via teleconference to discuss and develop the recommendations.

\section{Scoping review}

Our panel was more interested in breadth over depth and, as such, chose to use a scoping review for our literature search. Scoping reviews do not formally appraise the quality of or synthesize results of research papers and can generate a very large number of studies to search through. It did, however, allow us to rapidly identify key concepts and use papers with multiple study designs. ${ }^{10}$ With the help of a hospital librarian, the panel searched PubMed and Embase using the following search terms: medical educator, clinician educator, clinician teacher, career professional development, career choice, and professional role. The search was limited to articles from January 1, 2005 to December 7, 2015. Abstracts were reviewed independently by two panelists (RW and JA) to determine inclusion, and disagreements were resolved by consensus. Articles were distributed amongst the panel for critical appraisal using the following pre-determined categories: CE scope of practice, assessment of CEs, assessment of training programs, attracting CEs, faculty development, barriers and facilitators for CEs, and academic promotion. Thematic analysis of the included article summaries was performed by two authors (JA and RW).

\section{Survey}

The panel members divided the 17 Canadian medical schools and used referral sampling to identify individuals at each institution who currently or previously 


\begin{tabular}{|c|c|c|c|c|}
\hline & \multicolumn{2}{|c|}{$\begin{array}{l}\text { Database: Ovid MEDLINE(R) in-process \& other non-indexed } \\
\text { citations and Ovid MEDLINE(R) (1946 to present) }\end{array}$} & \multicolumn{2}{|c|}{ Database: Embase (1974 to 2016 January 05) } \\
\hline & Search terms & Articles & Search terms & Articles \\
\hline 1 & \multirow{6}{*}{$\begin{array}{l}\text { (medical educators or clinician educators or } \\
\text { clinical teachers).tw, kw. } \\
\text { (Medical faculty/or *medical education/) and } \\
\text { *teaching/ } \\
1 \text { or } 2 \\
\text { (recommends adj5 [training or education]).tw. } \\
\text { ([career or professional] adj development).tw, kw. } \\
\text { staff development/ }\end{array}$} & 2,409 & $\begin{array}{l}\text { (medical educators or clinician } \\
\text { educators or clinical teachers).tw. }\end{array}$ & 2,603 \\
\hline 2 & & 3,208 & $\begin{array}{l}\text { health educator/and medical } \\
\text { education/ }\end{array}$ & 232 \\
\hline 3 & & 5,410 & *teacher/and medical education/ & 860 \\
\hline 4 & & 5,557 & or/1-3 & 3,609 \\
\hline 5 & & 6,994 & career planning/ & 1,919 \\
\hline 6 & & 7,862 & $\begin{array}{l}\text { professional knowledge/ or } \\
\text { professional development/ }\end{array}$ & 16,959 \\
\hline 7 & career choice/ & 19,116 & $\begin{array}{l}\text { (recommends adj5 [training or } \\
\text { education]).tw. }\end{array}$ & 7,040 \\
\hline 8 & professional role/ & 9,533 & 5 or 6 or 7 & 25,475 \\
\hline 9 & or $/ 4-8$ & 47,192 & 4 and 8 & 187 \\
\hline 10 & 3 and 9 & 419 & limit 9 to $y r=$ "2005 - Current" & 176 \\
\hline 11 & limit 10 to yr = "2005 - Current" & 298 & remove duplicates from 10 & 174 \\
\hline 12 & remove duplicates from 11 & 293 & & \\
\hline
\end{tabular}

Figure 1. Search strategy for the literature review.

fulfilled the definition of a CE. By consensus, the panel came to a practical definition in order to enlist our sample of CEs. This was defined as: an emergency physician who holds or has beld a formal education position in the last 10 years and makes/made decisions about curriculum.

The panel identified 262 education leaders from 16 of the 17 medical schools (the panel was unable to identify a contact person at the Universite de Sherbrooke). By way of a structured written survey, educators were asked to identify the most important competencies $^{6}$ required for success in education leadership, whether they had acquired advanced training in medical education prior to assuming or during their position, and whether they would recommend advanced training to others prior to taking on that role.

\section{Results of the scoping review}

The search strategy is shown in Figure 1. After duplicates were removed, 437 articles remained. JA and RW reviewed the abstracts and agreed by consensus on 41 articles for a complete review (Figure 2). Several themes were identified from the systematic review of the literature: the importance of the CE role for the ongoing advancement of medical education, strategies for being a successful CE, descriptions of training programs, and the challenges associated with academic promotion for CEs.

Medical educators form a critical role to the advancement of a medical institution. ${ }^{6,11}$ This goes beyond expanding and refining the repertoire of medical school teaching. ${ }^{12}$ It also includes supporting the academic mission of the institution and adapting to the

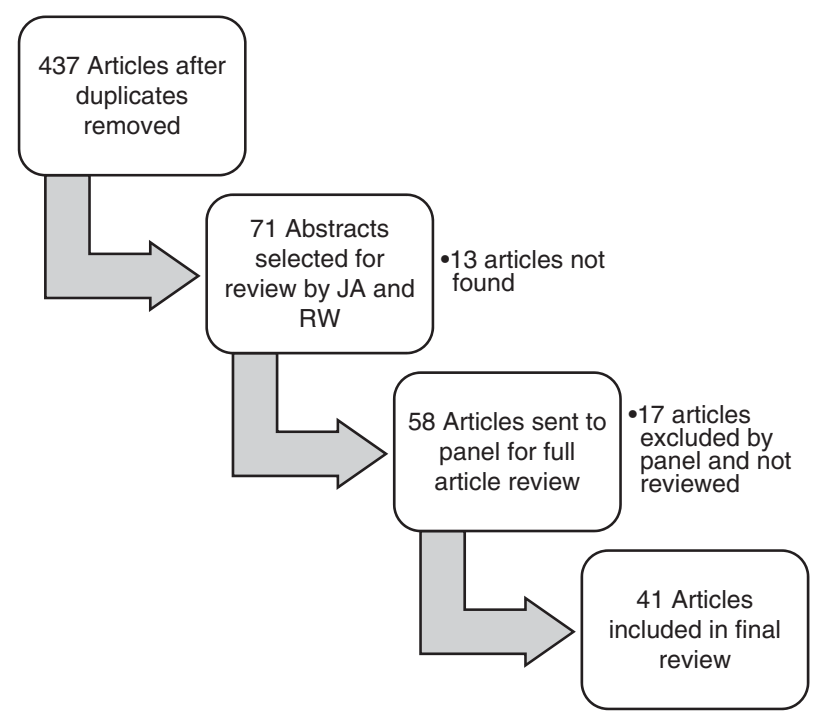

Figure 2. Review of articles from the scoping review.

changing environment of educational standards and accreditation.

A CE becomes a consultant to her or his colleagues and to the institution in which they work, helping them achieve the previous goals. Strategies for success as a CE have been identified: clarify what success means for you; seek mentorship; develop a niche and engage in relevant professional development; network; transform educational activities into scholarship; and seek funding and other resources. ${ }^{11}$

Experiential learning is no longer sufficient for becoming a CE. ${ }^{13}$ Training programs for medical education have exploded over the last two decades. There is a large number of master's programs, ${ }^{14}$ fellowships, ${ }^{15}$ and academies, ${ }^{16,17}$ Fellowships have been developed across 


\begin{tabular}{lc|}
\hline Table 1. Demographics of respondents $(\boldsymbol{n}=\mathbf{1 4 2})$ \\
\hline Demographics \\
\hline Training \\
FRCPC (EM) \\
FRCPC (PEM) \\
CCFP (EM) & $75(53 \%)$ \\
CCFP & $13(9 \%)$ \\
Other ${ }^{\text {a }}$ & $45(32 \%)$ \\
Years in practice & $1(1 \%)$ \\
$0-5$ & $8(6 \%)$ \\
$6-10$ & \\
$11-15$ & $28(20 \%)$ \\
$16-20$ & $29(20 \%)$ \\
$>20$ & $26(18 \%)$ \\
Not specified & $22(15 \%)$ \\
Type of practice & $31(22 \%)$ \\
Tertiary care ED & $6(4 \%)$ \\
Community ED & $135(95 \%)$ \\
Multiple types & $17(12 \%)$ \\
Other & $16(11 \%)$ \\
\hline aOther certifications listed include FRCPC (pediatrics), CSPO, ABP, ABEM. & $6(4 \%)$ \\
\hline
\end{tabular}

a Other certifications listed include FRCPC (pediatrics), CSPQ, ABP, ABEM.

specialties at individual medical schools, ${ }^{18}$ and there are specific fellowships for EM education ${ }^{19-21}$ and efforts to ensure the quality of these various training programs. ${ }^{22,23}$

CEs have historically faced challenges in academic promotion for a variety of reasons. ${ }^{24}$ Whereas some institutions have had success in accepting novel forms of scholarship, others still base promotion primarily on grants and peer-reviewed publications; ${ }^{25}$ whereas some CEs obtain/receive grants and publish, many produce other forms of scholarship. ${ }^{7}$

\section{Results from the survey of education leaders}

Of the identified 265 education leaders, 142 completed the survey for a response rate of $53.6 \%$. The survey was distributed electronically with a pre-notification message and three email reminders sent over 3 weeks in February 2016. The survey was created in FluidSurveys (Ottawa, ON), and the data were analysed using Excel. There was a broad range of certification and years of experience amongst the respondents (Table 1). Most of the respondents have spent the majority of their professional time in the clinical domain (Table 2). The majority of respondents recommended advanced training prior to taking on an educational leadership role (Table 3).

Greater than $50 \%$ of respondents felt that all of the competencies of a $\mathrm{CE}^{6}$ were important or very important (see Table 3). The degree of agreement

\begin{tabular}{|lcc|}
$\begin{array}{l}\text { Table 2. Percentage } \\
(\boldsymbol{n}=\mathbf{1 4 2})\end{array}$ & time devoted to & professional roles \\
\hline Professional roles & Mean \% (+/-SD) & Range (min., max.) \\
\hline Clinical & $62.1(+/-16.6)$ & $60(10,90)$ \\
Education & $18.3(+/-10.4)$ & $15(0,70)$ \\
Administrative & $13.8(+/-13.1)$ & $10(0,70)$ \\
Research & $5.3(+/-7.7)$ & $5(0,45)$ \\
Other & $0.3(+/-2.6)$ & $0(0,30)$ \\
\hline
\end{tabular}

varied by competency and by the education leadership role (Table 4). The competencies that were consistently identified by all roles were leadership, communication skills, assessment, and curriculum development.

\section{Presentation of results and draft recommendations at the Academic Symposium}

The recommendations that were drafted by the panel were presented to 100 EPs at the 2016 CAEP Academic Symposium on June 4, 2016. Through a live survey poll and facilitated discussion, audience members provided feedback to the expert panel. The main themes identified were to categorize the recommendations at the individual, the academic departments and divisions (AD\&D), and CAEP Academic Section levels. The audience discouraged having recommendations at the specific CE competency level for each type of leadership role, because the competencies were too granular and were subject to institutional and role variability.

\section{RECOMMENDATIONS}

Recommendations for emergency physicians and residents (our future clinician educators):

1) Advanced training in medical education is recommended for any EP or resident who plans to take on an education leadership role.

2) Advanced training should take the form of at least one of the following: targeted courses/workshops, formal certifications, a fellowship, or a master's degree; the skills acquired should be applicable to the role that he or she plans to pursue.

3) EPs or residents who consider becoming CEs should seek out mentorship to consider all career pathways and training opportunities. 
Training future clinician educators in EM

\begin{tabular}{|c|c|c|c|c|c|}
\hline & $\begin{array}{c}\text { Very } \\
\text { important }\end{array}$ & Important & Neutral & $\begin{array}{c}\text { Only } \\
\text { somewhat } \\
\text { important }\end{array}$ & $\begin{array}{c}\text { Not } \\
\text { important } \\
\text { at all }\end{array}$ \\
\hline \multicolumn{6}{|l|}{ With Med Ed training } \\
\hline Education theory & $18(30 \%)$ & $20(33 \%)$ & $9(15 \%)$ & $12(20 \%)$ & $2(3 \%)$ \\
\hline Educational psychology & $13(25 \%)$ & $19(37 \%)$ & $11(21 \%)$ & $7(13 \%)$ & $2(4 \%)$ \\
\hline Clinical teaching & $20(43 \%)$ & $18(38 \%)$ & $9(19 \%)$ & $0(0 \%)$ & $0(0 \%)$ \\
\hline Teaching outside of clinical care areas & $13(31 \%)$ & $18(43 \%)$ & $11(26 \%)$ & $0(0 \%)$ & $0(0 \%)$ \\
\hline Communication skills & $31(69 \%)$ & $14(31 \%)$ & $0(0 \%)$ & $0(0 \%)$ & $0(0 \%)$ \\
\hline Curriculum development & $26(55 \%)$ & $18(38 \%)$ & $0(0 \%)$ & $3(6 \%)$ & $0(0 \%)$ \\
\hline Assessment & $27(55 \%)$ & $18(37 \%)$ & $2(4 \%)$ & $2(4 \%)$ & $0(0 \%)$ \\
\hline Program evaluation & $21(46 \%)$ & $15(33 \%)$ & $8(17 \%)$ & $2(4 \%)$ & $0(0 \%)$ \\
\hline Faculty development & $17(35 \%)$ & $23(47 \%)$ & $6(12 \%)$ & $1(2 \%)$ & $2(4 \%)$ \\
\hline Administration of educational programs & $14(30 \%)$ & $11(24 \%)$ & $17(37 \%)$ & $4(9 \%)$ & $0(0 \%)$ \\
\hline Leadership & $18(41 \%)$ & $23(52 \%)$ & $3(7 \%)$ & $0(0 \%)$ & $0(0 \%)$ \\
\hline Organizational and/or jurisdictional issues & $5(13 \%)$ & $16(42 \%)$ & $9(24 \%)$ & $6(16 \%)$ & $2(5 \%)$ \\
\hline Education research or scholarship & $8(19 \%)$ & $16(37 \%)$ & $8(19 \%)$ & $8(19 \%)$ & $3(7 \%)$ \\
\hline Recommend advanced Med Ed training & $17(47 \%)$ & $15(42 \%)$ & $3(8 \%)$ & $1(3 \%)$ & $0(0 \%)$ \\
\hline \multicolumn{6}{|l|}{ Without Med Ed training } \\
\hline Education theory & $8(22 \%)$ & $19(51 \%)$ & $3(8 \%)$ & $0(0 \%)$ & $7(19 \%)$ \\
\hline Educational psychology & $4(12 \%)$ & $13(39 \%)$ & $5(15 \%)$ & $6(18 \%)$ & $5(15 \%)$ \\
\hline Clinical teaching & $9(33 \%)$ & $14(52 \%)$ & $1(4 \%)$ & $2(7 \%)$ & $1(4 \%)$ \\
\hline Teaching outside of clinical care areas & $3(12 \%)$ & $14(56 \%)$ & $4(16 \%)$ & $3(12 \%)$ & $1(4 \%)$ \\
\hline Communication skills & $15(60 \%)$ & $10(40 \%)$ & $0(0 \%)$ & $0(0 \%)$ & $0(0 \%)$ \\
\hline Curriculum development & $12(44 \%)$ & $7(26 \%)$ & $6(22 \%)$ & $2(7 \%)$ & $0(0 \%)$ \\
\hline Assessment & $15(56 \%)$ & $10(37 \%)$ & $2(7 \%)$ & $0(0 \%)$ & $0(0 \%)$ \\
\hline Program evaluation & $12(44 \%)$ & $9(33 \%)$ & $4(15 \%)$ & $2(7 \%)$ & $0(0 \%)$ \\
\hline Faculty development & $6(22 \%)$ & $17(63 \%)$ & $2(7 \%)$ & $1(4 \%)$ & $1(4 \%)$ \\
\hline Administration of educational programs & $9(35 \%)$ & $13(50 \%)$ & $4(15 \%)$ & $0(0 \%)$ & $0(0 \%)$ \\
\hline Leadership & $15(56 \%)$ & $8(30 \%)$ & $4(15 \%)$ & $0(0 \%)$ & $0(0 \%)$ \\
\hline Organizational and/or jurisdictional issues & $4(17 \%)$ & $14(58 \%)$ & $5(21 \%)$ & $1(4 \%)$ & $0(0 \%)$ \\
\hline Education research or scholarship & $2(8 \%)$ & $7(28 \%)$ & $10(40 \%)$ & $1(4 \%)$ & $5(20 \%)$ \\
\hline Recommend advanced Med Ed training & $7(19 \%)$ & $14(39 \%)$ & $11(31 \%)$ & $1(3 \%)$ & $3(8 \%)$ \\
\hline
\end{tabular}

Recommendations for academic departments and divisions:

1) AD\&D should work with their institutional strategic plans to regularly perform a needs assessment of their future CE needs. This will allow them to identify and encourage potential individuals who would fulfill education leadership roles.

2) $A D \& D$ should provide advanced training and mentorship opportunities, protected time or preferential scheduling, and financial support to complete advanced training.

3) $\mathrm{AD} \& \mathrm{D}$ should advocate for the recognition of education scholarship in their institution's promotions process.

Recommendations for the CAEP Academic Section:

1) To advance EM, the CAEP Academic Section should support the mentorship and networking of CEs across Canada.

\section{Discussion of recommendations}

The panel sees a tremendous change on the horizon for EM education. To be prepared for the future, our CEs need to have the full set of skills and knowledge required to become education consultants. ${ }^{6}$ This also resonated from the results of our education leaders survey. This set of skills is too complex to learn on the job, and specific training will be necessary. This will put our clinicians in a position to achieve all of the competencies of a CE. This will require action from individuals, $\mathrm{AD} \& \mathrm{D}$, and the CAEP Academic Section.

EPs and residents should receive formal training in medical education prior to taking on a leadership role. This recommendation came from the majority of respondents of our survey. The endorsement was greater for those with previous medical education training and may represent some degree of cognitive dissonance bias in both groups. Those who have previous training may be more likely to think it was 


\begin{tabular}{|c|c|c|c|c|c|c|c|}
\hline & $\begin{array}{l}\text { Education } \\
\text { theory }\end{array}$ & $\begin{array}{l}\text { Educational } \\
\text { psychology }\end{array}$ & Clinical teaching & $\begin{array}{l}\text { Teaching outside of } \\
\text { clinical care areas }\end{array}$ & Communication skills & $\begin{array}{l}\text { Curriculum } \\
\text { development }\end{array}$ & Assessment \\
\hline Clerkship Director & $8(53 \%)$ & $6(55 \%)$ & $9(90 \%)$ & $6(75 \%)$ & $8(100 \%)$ & $9(90 \%)$ & $10(100 \%)$ \\
\hline Residency Program Director & $10(59 \%)$ & $7(47 \%)$ & $15(83 \%)$ & $11(79 \%)$ & $15(100 \%)$ & $16(94 \%)$ & $18(100 \%)$ \\
\hline Simulation Director & $10(77 \%)$ & $9(69 \%)$ & $6(75 \%)$ & $6(75 \%)$ & $9(100 \%)$ & $7(88 \%)$ & $6(67 \%)$ \\
\hline $\begin{array}{l}\text { Faculty Development } \\
\text { Director }\end{array}$ & $5(83 \%)$ & $5(83 \%)$ & $4(100 \%)$ & $4(100 \%)$ & $5(100 \%)$ & $5(100 \%)$ & $4(80 \%)$ \\
\hline $\begin{array}{l}\text { Ultrasound Education } \\
\text { Director }\end{array}$ & $1(100 \%)$ & $0(0 \%)$ & $1(100 \%)$ & $1(100 \%)$ & $1(100 \%)$ & $1(100 \%)$ & $1(100 \%)$ \\
\hline $\begin{array}{l}\text { Education Scholarship } \\
\text { Position }\end{array}$ & $6(75 \%)$ & $5(71 \%)$ & $2(50 \%)$ & $2(50 \%)$ & $4(100 \%)$ & $4(100 \%)$ & $4(100 \%)$ \\
\hline Fellowship Director & $3(75 \%)$ & $3(75 \%)$ & $1(33 \%)$ & $2(67 \%)$ & $3(100 \%)$ & $3(100 \%)$ & $3(100 \%)$ \\
\hline Dean & $4(67 \%)$ & $2(67 \%)$ & $4(80 \%)$ & $2(50 \%)$ & $4(100 \%)$ & $3(60 \%)$ & $5(100 \%)$ \\
\hline UG Director / Pre-clerkship & $2(67 \%)$ & $1(33 \%)$ & $3(100 \%)$ & $2(67 \%)$ & $3(100 \%)$ & $1(33 \%)$ & $3(100 \%)$ \\
\hline PG EM Rotation Coordinator & $3(50 \%)$ & $2(33 \%)$ & $5(83 \%)$ & $4(67 \%)$ & $6(100 \%)$ & $4(67 \%)$ & $5(83 \%)$ \\
\hline CME Director & $2(67 \%)$ & $1(50 \%)$ & $1(100 \%)$ & $1(100 \%)$ & $1(100 \%)$ & $1(100 \%)$ & $1(100 \%)$ \\
\hline Course Director & $3(75 \%)$ & $2(67 \%)$ & $2(100 \%)$ & $1(50 \%)$ & $2(100 \%)$ & $2(100 \%)$ & $2(100 \%)$ \\
\hline \multirow[t]{2}{*}{ Other } & $8(65 \%)$ & $6(54 \%)$ & $8(85 \%)$ & $6(58 \%)$ & $9(100 \%)$ & $7(69 \%)$ & $8(92 \%)$ \\
\hline & $\begin{array}{l}\text { Program } \\
\text { evaluation }\end{array}$ & $\begin{array}{c}\text { Faculty } \\
\text { development }\end{array}$ & $\begin{array}{l}\text { Administration of } \\
\text { educational programs }\end{array}$ & Leadership & $\begin{array}{l}\text { Organizational and/or } \\
\text { jurisdictional issues }\end{array}$ & $\begin{array}{l}\text { Education } \\
\text { research or } \\
\text { scholarship }\end{array}$ & $\begin{array}{l}\text { Recommend advanced } \\
\text { medical education training? }\end{array}$ \\
\hline Clerkship Director & $7(70 \%)$ & $5(56 \%)$ & $8(80 \%)$ & $8(89 \%)$ & $4(67 \%)$ & $5(56 \%)$ & $7(88 \%)$ \\
\hline Residency Program Director & $15(94 \%)$ & $14(82 \%)$ & $13(81 \%)$ & $14(82 \%)$ & $6(46 \%)$ & $8(57 \%)$ & $17(63 \%)$ \\
\hline Simulation Director & $5(63 \%)$ & $7(88 \%)$ & $7(88 \%)$ & $7(100 \%)$ & $3(43 \%)$ & $3(43 \%)$ & $3(60 \%)$ \\
\hline $\begin{array}{l}\text { Faculty Development } \\
\text { Director }\end{array}$ & $3(75 \%)$ & $5(100 \%)$ & $3(75 \%)$ & $5(100 \%)$ & $3(75 \%)$ & $2(50 \%)$ & $4(100 \%)$ \\
\hline $\begin{array}{l}\text { Ultrasound Education } \\
\text { Director }\end{array}$ & $1(100 \%)$ & $1(100 \%)$ & $1(100 \%)$ & $1(100 \%)$ & $0(0 \%)$ & $1(100 \%)$ & $1(100 \%)$ \\
\hline $\begin{array}{l}\text { Education Scholarship } \\
\text { Position }\end{array}$ & $4(80 \%)$ & $3(75 \%)$ & $1(25 \%)$ & $4(100 \%)$ & $3(75 \%)$ & $4(100 \%)$ & $3(75 \%)$ \\
\hline Fellowship Director & $3(100 \%)$ & $3(100 \%)$ & $2(67 \%)$ & $3(100 \%)$ & $2(67 \%)$ & $1(33 \%)$ & $4(80 \%)$ \\
\hline Dean & $4(80 \%)$ & $5(83 \%)$ & $5(100 \%)$ & $4(100 \%)$ & $3(100 \%)$ & $1(33 \%)$ & $6(100 \%)$ \\
\hline UG Director / Pre-clerkship & $2(67 \%)$ & $3(100 \%)$ & $1(33 \%)$ & $2(67 \%)$ & $1(33 \%)$ & $0(0 \%)$ & $0(0 \%)$ \\
\hline PG EM Rotation Coordinator & $4(67 \%)$ & $5(83 \%)$ & $2(33 \%)$ & $5(83 \%)$ & $4(67 \%)$ & $2(33 \%)$ & $0(0 \%)$ \\
\hline CME Director & $1(100 \%)$ & $1(100 \%)$ & $0(0 \%)$ & $1(100 \%)$ & $1(100 \%)$ & $0(0 \%)$ & $0(0 \%)$ \\
\hline Course Director & $1(50 \%)$ & $2(67 \%)$ & $0(0 \%)$ & $2(100 \%)$ & $2(100 \%)$ & $1(33 \%)$ & $0(0 \%)$ \\
\hline Other & $7(77 \%)$ & $9(87 \%)$ & $4(62 \%)$ & $8(92 \%)$ & $7(82 \%)$ & $5(42 \%)$ & $8(67 \%)$ \\
\hline
\end{tabular}


valuable because they invested their time and money. Those without previous training may be less likely to think it was valuable because they would potentially be admitting that they were not as prepared as they should have been for the role they took on. Keeping this bias in mind, $58 \%$ of those without advanced training still felt it should be required.

There is a myriad of training opportunities available for medical education. Within training options, there are multiple formats. A master's program can be face to face, distance learning, or a hybrid model. ${ }^{14}$ Not all institutions will have local access to training, so travel may be required. Because of these factors, it will be difficult for prospective CEs to know what the best training is for them. The literature search ${ }^{11}$ and our survey both strongly support the need for mentorship from senior CEs to guide them through this process. Additionally, individuals should discuss their interests with their department heads who can advise them on future career opportunities.

Training CEs will require strong leadership from $\mathrm{AD} \& \mathrm{D}$. $\mathrm{AD} \& \mathrm{D}$ needs to work with their institutional strategic plans to identify their educational goals. From here, they will be able to determine where their CE needs are. CE positions need to be planned for in advance, and potential candidates should be identified. As soon as candidates are identified, they should be connected with potential mentors who can guide them through their training. This will allow candidates to tailor their advanced training towards the role that they plan to take on.

$\mathrm{AD} \& \mathrm{D}$ also needs to advocate for training opportunities at their own institution to make them more accessible. Additionally, future CEs need to be supported. Getting advanced training in medical education is expensive and time-consuming. From our survey, individuals who completed advanced training received very little support to complete advanced training, and those who did not complete training cited lack of support as a barrier. This would ideally involve protected time and/or financial support but, at a minimum, requires preferential scheduling to complete the advanced training. These measures will ensure that taking on advanced training is feasible for many. As a speciality, we will need a constant supply of CEs, because the number of $\mathrm{CE}$ positions in EM are vast and expanding.

AD\&D also needs to advocate for academic promotions criteria that recognize education scholarship. This was identified in the literature as a significant barrier for many CEs. ${ }^{24,25}$ The traditional clinician scientist pathway does not always fit the career trajectory of a CE. Additional forms of scholarship need to be represented in the portfolio of a CE. This will ensure that CEs feel their scholarly contributions are valued.

The CAEP Academic Section can play a networking role towards this goal. The Education Scholarship Committee is a community of practice for Canadian EM educators with representatives across Canada. This working group can serve as a contact point for future CEs looking for mentorship towards their career goals.

In summary, these recommendations serve as a framework for training and supporting the next generation of Canadian EM medical educators.

Acknowledgements: The authors would like to acknowledge Alexandra (Sascha) Davis at the Ottawa Civic Library and Angela Marcantonio at the University of Ottawa EM Research Group for their help with the literature search. The authors also thank Kelly Wyatt from the CAEP office for her assistance with panel meetings, information management, and the coordination of the symposium.

Competing interests: None declared.

\section{REFERENCES}

1. Langhan TS. Simulation training for emergency medicine residents: time to move forward. CFEM 2008;10(5):467-9; 470-3.

2. Woo M, Frank J, Lee A. Point-of-care ultrasonography adoption in Canada: using diffusion theory and the evaluation tool for ultrasound skills development and education (ETUDE). Can 7 Emerg Med 2013;16(5):245-51; doi: doi:10.2310/8000.2013.131243.

3. Cadogan M, Thoma B, Chan TM, et al. Free Open Access Meducation (FOAM): the rise of emergency medicine and critical care blogs and podcasts (2002 - 2013). 2014:20142016, doi:10.1136/emermed-2013-203502.

4. Iobst WF, Sherbino J, Cate O Ten, et al. Competency. -based medical education in postgraduate medical education. Med Teach 2010;32(8):651-6; doi:10.3109/0142159X.2010.500709.

5. Sherbino J. Education scholarship: the next step for our specialty. 2010;12(4).

6. Sherbino J, Frank JR, Ed MA, et al. Defining the key roles and competencies of the clinician - educator of the $21 \mathrm{st}$ century: a national mixed-methods study. 2014;89(5):783-9; doi:10.1097/ACM.0000000000000217.

7. Sherbino J, van Melle E, Bandiera G, et al. Education scholarship in emergency medicine part 1: innovating and improving teaching and learning. Can 7 E 2014;15(Suppl 1): S1-5; doi:10.2310/8000.2014.141454.

8. Bandiera $\mathrm{G}$, Leblanc $\mathrm{C}$, Regehr $\mathrm{G}$, et al. Education scholarship in emergency medicine part 2: supporting and developing scholars. CFEM 2014;16(Suppl 1):S6-12; doi: $10.2310 / 8000.2014 .141455$.

9. Bhanji F, Cheng A, Frank JR, et al. Education scholarship in emergency medicine part 3: a "how-to" guide. CFEM 2014;16 (Suppl 1):S13-8; doi:10.2310/8000.2014.141456. 
10. Arksey H, O'Malley L. Scoping studies: towards a methodological framework. Int 7 Soc Res Methodol 2005;8(1):19-32; doi:10.1080/1364557032000119616.

11. Castiglioni A, Aagaard E, Spencer A, et al. Succeeding as a clinician educator: useful tips and resources. 136-40; doi:10.1007/s11606-012-2156-8.

12. Searle NS, Hatem CJ, Perkowski L. Why invest in an educational fellowship program? 2006;81(11):936-40.

13. Sullivan GM. Resources for clinicians becoming clinician educators. 2015: 153-5.

14. Tekian A, Harris I. Preparing health professions education leaders worldwide: a description of masters-level programs. Med Teach 2012;34(1):52-8; doi:10.3109/0142159X. 2011.599895 .

15. Thompson BM, Searle NS, Gruppen LD, et al. A national survey of education fellowships. 2011;1:2-5; doi:10.3402/ meo.v16i0.5642.

16. Searle NS, Thompson BM, Friedland JA, et al. The prevalence and practice of academies of medical educators: a survey of U.S. medical schools. Acad Med 2010;85(1):48-56; doi:10.1097/ACM.0b013e3181c4846b.

17. Lamantia J, Kuhn GJ, Searle NS. The CORD Academy for scholarship in education in emergency medicine. Acad Emerg Med 2010;17(Suppl 2):13-5; doi:10.1111/j.1553$\underline{2712.2010 .00895 . x}$.
18. Steinert Y, Mcleod PJ. From novice to informed educator: the teaching scholars program for educators in the health sciences. 2006;81(11):969-74.

19. Lin M, Santen SA, Yarris LM, et al. Development of a training needs assessment for an education scholarship fellowship in emergency medicine. 2012: 1419-24; doi:10.1111/acem.12035.

20. Coates WC, Lin M, Clarke S, et al. Defining a core curriculum for education scholarship fellowships in emergency medicine. 2012: 1411-8; doi:10.1111/acem.12036.

21. Yarris LM, Coates WC. Creating educational leaders: experiences with two education fellowships in emergency medicine. 2012: 1481-5; doi:10.1111/acem.12042.

22. Al-subait R, Elzubeir M. Evaluating a masters of medical education program: attaining minimum quality standards?. 2012: 67-74; doi:10.3109/0142159X.2012.656746.

23. Gruppen LD, Simpson D, Searle NS, et al. Educational fellowship programs: common themes and overarching issues. 2006;81(11):990-4.

24. Alexandraki I, Mooradian A. Academic advancement of clinician educators: why is it so difficult? 2011: 1118-25; doi:10.1111/j.1742-1241.2011.02780.x.

25. Van Melle E, Lockyer J, Curran V, et al. Toward a common understanding: supporting and promoting education scholarship for medical school faculty. Med Educ 2014; 48(12):1190-200; doi:10.1111/medu.12543. 